\title{
PENGARUH MANAJEMEN PERUBAHAN TERHADAP ORGANISASI PEMBELAJARAN SERTA DAMPAKNYA TERHADAP KINERJA PEGAWAI PADA PT. KAI (PERSERO) DAOP II BANDUNG
}

\author{
JOELIATY \\ FEB Universitas Padjadjaran \\ joeliaty@yahoo.co.id \\ YAYAN. FIRMANSYAH \\ STIE INABA \\ yayan.firmansyah.mgt@gmail.com
}

\begin{abstract}
Changes of business environment that is increasingly fast encountered by PT.KAI (PERSERO) DAOP II Bandung. It requires this company to be adapted. Adapting with this is condition is a must. The company's ability to address the challenges of current and future become one of the power that must be owned by the company.

The purpose of this research is to discover to discover effect change management on learning organization and its implication on employee performance in PT.KAI (PERSERO) DAOP II Bandung. This research used survey method by distributing questionnaires to 100 respondents. The result of Effect of change management on employee performance through learning organization is about $41.11 \%$.
\end{abstract}

Keywords : change management, learning organization, employee performance

\section{Pendahuluan}

Seiring dengan perubahan jaman dengan lingkungan yang penuh turbulensi dan dinamika, membentuk arena kompetisi yang semakin kuat dan ketat. Penulis menyitir pendapat Charles Darwin tentang perusahaan yang mampu mempunyai umur panjang, berpendapat "bukan yang terkuat yang mampu berumur panjang, melainkan yang paling adaptif" (Rhenald Kasali, 17 : 2007). Perubahan dalam organisasi apapun memainkan peran yang penting untuk meraih kesuksesan di banyak organisasi (Dumpy dan Stace : 1993 ; Reib: 2012 ; Alireza Shirvani at al : 2013; 1751). Perubahan menjadi salah satu kebutuhan organisasi yang sangat vital dilakukan, perubahan yang terjadi sekarang ini lebih cenderung disebabkan perubahan yang direncanakan daripada perubahan yang tidak direncanakan (Greenberg dan Baron 1997 :550; Wibowo 2012 :88). Kemampuan untuk mengelola perubahan akhirnya menjadi kunci sukses dalam mencapai tujuan dari dilakukannya perubahan tersebut. Salah satu sasaran manajemen perubahan adalah mengupayakan agar proses transformasi tersebut berlangsung dalam waktu yang relatif cepat dan akurat dengan meminimalisasi kesulitan-kesulitan.

PT. Kereta Api Indonesia (PERSERO) DAOP 2 Bandung, sebagai entitas bisnis, yang dewasa ini persaingan hypercompetitive dalam industri jasa transportasi, diharuskan dapat menjawab kebutuhan para stakeholders ini juga sesuai dengan visi PT. Kereta Api Indonesia (PERSERO) yaitu "Menjadi penyedia jasa perkeretaapian terbaik yang fokus pada pelayanan pelanggan dan memenuhi harapan stakeholders". Dorongan untuk berubah pada PT. Kereta Api (PERSERO) DAOP II Bandung, Perubahan yang dilakukan disini adalah perubahan yang terencana menurut Geernberg dan Baron (1997 : 550) dalam Wibowo (2012 : 88) perubahan terencana karena adanya dorongan seperti : perubahan dalam produk atau jasa, 
perubahan dalam ukuran dan struktur organisasi, perubahan dalam sistem administrasi, dan yang terakhir adalah pengenalan teknologi baru.

Perubahan merupakan suatu fenomena yang tidak bisa dihindari dalam kehidupan organisasi, meskipun banyak yang berpendapat bahwa kecepatan dan besaran perubahan telah meningkat secara signifikan beberapa tahun belakangan ini. Penelitian yang dilakukan The Institute of Management tahun 1991 menunjukkan bahwa 90\% organisasi menjadi lebih ramping dan datar. Pada tahun 1992 dilaporkan bahwa 80\% manajer merespon dengan merestruktur perusahannya dalam lima tahun terakhir. Oleh karena itu, kita melihat bahwa dalam waktu yang relatif pendek, kebanyakan organisasi dan pekerjaannya telah mengalami perubahan secara substansial tentang apa yang mereka lakukan dan bagaimana mereka melakukannya (Burnes, 2000:250).

Manajemen perubahan tidak akan berhasil tanpa adanya implemtasi organisasi pembelajaran yang menyediakan ruang untuk selalu improvement, diharapakan menjadi atau mempertahankan sebagai leader market, salah satu saran untuk mencapinya dengan kinerja pegawai yang baik, disini diperlukan peranan organisasi pembelajaran agar keberhasilan perubahan oraganisasi dapat berjalan efektif dan efesien sehingga akan tercapai visi perusahaan. Fokus proses perubahan membentuk organisasi pembelajaran, dan membentuk mental model untuk memahami kegiatan organisasi dan megambil kebijakan yang sesuai untuk mengelola kualitas antara semua eksekutif, manajer dan key staff. (Albert, Michael: 47 :2005). Hasil studi empirik yang dilakukan oleh Albert, Michael (2006) mendapatkan temuan adanya pengaruh manajemen perubahan terhadap terbentuknya organisasi pembelajaran, studi ini dilakukan di Laboraturium Hewlett-Packard Company. Dari pengamatan penulis di PT KAI (PERSERO) DAOP II belum terlihat adanya prasarana yang menunjang secara utuh untuk organisasi pembelajaran diduga ini merupakan salah satu faktor kenapa kinerja karyawan tidak dapat tercapai, seperti yang dikemukakan sebelumnya manajemen perubahan dapat berjalan efektif dan efisien jika didukung dengan organisasi pembelajaran. Kita mengetahui bahwa perusahaan-perusahaan Jepang telah mencapai kemajuan sehubungan dengan posisi mereka dalam persaingan internasional. Menurut Ikujiro Nonaka, keberhasilan perusahaan-perusahaan Jepang bukanlah disebabkan keberhasilan mereka dalam bidang produksi : karena dapat mencapi harga murah: karena mereka memiliki hubungan dekat : serta erat dengan pelanggan mereka. Perusahaan-perusahaan di Jepang telah mencapai keberhasilan yang luar biasa karena keterampilan-keterampilan dan keahlian mereka dalam hal "menciptakan pengetahuan keorganisasian" (Nonaka, 1995 :3) dalam Winardi 2010, yang dimaksud olehnya dengan penciptaan pengetahuan keorganisasian yaitu kemampuan pengetahuan baru-kemudian menyebarkanya melalui seluruh organisasi tersebut dan "memasukannya"ke dalam produk-produk, servis-servis, serta sistem-sistem.

Organisasi pembelajaran, dimana setiap individu menunjukan perilaku perbaikan dalam berbagai aspek melalui proses belajar, maka kinerja individu dapat diperbaiki secara terus menerus yang pada akhirnya akan berdampak pula pada peningkatan kinerja pegawai. Hal ini senada dengan William Looney dan Air Force Lt Gen. Charles L. Johnson, II (dikutip oleh Anderson et.al, $2004:$ 1) yang berpendapat bahwa : organisasi pembelajaran sebagai cara untuk memperbaiki efisiensi kerja, membagi informasi dengan baik lagi, mengembangakan akses yang lebih fleksibel pada pelatihan, memperluas sumber untuk pemecahan masalah ; meningkatkan pilihan dalam belajar dan akhirnya membuat belajar menjadi bagian keseharian dalam lingkungan kerja. Komitmen pemimpin sangat dibutuhkan untuk keberhasilan implementasinya. Penelitian Pool (2002) dalam Agapita Sri H (2006) menunjukan adanya pengaruh positif dan signifikan antara penetapan organisasi pembelajaran dengan motivasi manajer untuk meningkatkan kinerjanya. 


\section{Kajian Pustaka}

Salah satu pendekatan proses perubahan yang menjadi rujukan di kemukakan oleh seorang ilmuwan John P. Kotter dari Harvard Bussines School, Massachusetts, United States dalam bukunya Leading Change: Why Transformation Efforts Fail, dalam bukunya John P.Kotter mengapa proses transformasi mengalami kegagalan, dan sekaligus memberikan solusi agar proses transformasi berhasil, model ini lebih dikenal dengan nama Kotter's 8-step method. Model ini sudah di uji dibeberapa penelitian, seperti penelitian yang dilakukan oleh Amin Soebagyo (2009) model di uji secara empirik pada PT TELKOM, mendapatkan temuan bahwa kedelapan tahap proses transformasi, tahapan pencariran status quo dan tahap penanaman akar perubahan secara kokoh dalam kultur perusahaan dari Kotter yang dimplementasikan secara baik berpengaruh positif dan signifikan terhadap keberhasilan proses tranformasi. Pada tahun 2011 penelitian tentang proses manajemen perubahan yang di lakukan oleh, Ledy Primasary, mendapatkan temuan adanya pengaruh positif proses manajemen perubahan terhadap program transformasi bisnis. Hal ini dikuatkan oleh bukti penelitian yang dilakukan oleh Alireza Shirvani et al (2013) yang melakukan penelitan pada perusahaan distribusi gas di Provinsi Esfahan, Iran. Hasil dari studi ini mengungkapkan bahwa perusahaan ini, dengan menggunakan Kotter's 8-step method, sukses dalam membuat keadaan mendesak, membentuk kekuatan koalisi, membuat perubahan visi, mengkomunikasikan visi, membuat kemenangan jangka pendek, dan membangun perubahan. Tetapi organisasi ini tidak berhasil memindahkan hambatan-hambatan yang ada dan perubahan dalam budaya perusahaan. Langkah keenam, membuat kemenangankemenangan jangka pendek, menghasilkan tingkat keberhasilan yang sangat tinggi dengan menghilangkan hambatan-hambatan yang bisa meminimalkan tingkat kesuksesan, dengan menerapakan Kotter's 8-step method, mampu menghadapi perubuhan. Selain itu ada literature study tentang Kotter's 8-step method yang dilakukan oleh Appelbaum, Steven H et al (2012) dalam studi ini mendapatkan temuan bahwa Kotter's change management model dapat menjadi rujukan terbaik dan implemtatif dalam tahapan proses perubahan, dan banyak para ilmuan yang konsensus bahwa Kotter's change management model merupakan pendekatan yang terbaik untuk mengurangi kesalahan dalam proses perubahan, walaupun model ini jika tidak dimodifikasi yang tepat mempunyai kelemahannya karena terlalu rigid. Walaupun ada sisi kekurangan dari model ini Stagalas, Nicole. (2010;37), menyakini dan menguatkan bahwa model Kotter memberikan wawasan mendalam langkah-langkah tindakan yang lebih rinci yang dapat menjamin aplikasi yang sesuai dan relevan dari proses yang diuraikan.

Kemampuan perusahaan dalam menjalankan mengelola proses perubahan berpengaruh terhadap implementasi organisasi pembelajaran yang dilakukan oleh organisasi (Albert, Michael 2005 \& 2006), salah satu cara organisasi berhasil dalam mengelola proses perubahan harus terciptanya organisasi pembelajaran yang baik, hal ini sudah di uji secara empirik oleh berapa peneliti seperti Haque, Md Mahbubul (2008) dalam desertasinya pada Graduate School of Education and Psychology Pepperdine University. USA. Menguji model organisasi pembelajaran model Watkins dan Marsick, mendapat temuan bahwa organisasi pembelajar berpengaruh dan signifikan terhadap kemampuan organisasi dalam menghadapai perubahan, hal senada juga penelitian yang dilakukan oleh Mohammad Traheri R. et al (2013), dengan temuan hubungan yang signifikan antara organisasi pembelajaran dan kesiapan organisasi untuk perubahan, studi ini dilakukan di Agricultural Bank of Borujed City, Iran. Kemampuan organisasi untuk belajar berjalan salah satu sumber yang benar keunggulan kompetitif.

Beberapa peneliti sebelumnya mengenai organisasi pembelajar seperti yang dilakukan oleh Small (2006 ; 284) membuat kajian menyeluruh literatur yang melibatkan studi Argyris 
dan Schön (1978); Boud dan Middleton (2003); Brown dan Duguid (1996); De Geus (1999), Gibson dan Vermeulen (2003); Huber (1996); Keating, Robinson, dan Clemson (1996); Kock, McQueen, dan Corner (1997); Lave dan Wenger (1991); Loewen dan Loo (2004); Moilanen (2001); Örtenblad (2004); Pedler, Burgyne, dan Boydell (1997); Beberapa penulis murni berfokus pada pengembangan pendekatan yang ditujukan untuk individu sebagai titik awal dalam rantai interaksi yang bisa pergi untuk membentuk proses selanjutnya belajar dalam kelompok, praktek masyarakat, organisasi belajar dan kemungkinan hasil dari menciptakan sebuah organisasi pembelajaran.

Penelitian ini mendukung perspektif Watkins dan Marsick (1993 , 1996, 1999 ), yang mencatat bahwa dalam organisasi pembelajaran, belajar terjadi pada individu, kelompok, dan tingkat organisasi. Penulis mencoba untuk mengukur pembelajaran dalam organisasi untuk mencakup semua ketiga tingkatan untuk mencapai perspektif yang komprehensif (Rush, Rosalee Billingslea. 2011; 48-49). Calvert et al .(1994; Haque, Md Mahbubul 2008 ; 55) menjelaskan bahwa aspek yang saling berhubungan belajar di berbagai tingkatan menciptakan berbagai persepsi, yang membuat kontribusi berguna dalam memahami konsep. Sejumlah faktor mendorong penulis untuk pilih model ini. Pertama, Redding ( 1997) dan Örtenblad ( 2002) didalam Md Mahbubul (2008 ; 55) mencatat bahwa kerangka dikembangkan oleh Watkins dan Marsick adalah salah satu dari beberapa alat yang mengukur belajar ditingkat individu, tingkat tim, dan tingkat organisasi. Kedua, kerangka kerja ini memerlukan seperangkat lintas dimensi yang divalidasi dalam pendekatan organisasi pembelajaran terkemuka lainnya (Senge,1990; . Marquardt, 2002). Ketiga, kerangka telah dikenakan luas keandalannya dan pengujian validitas dibandingkan dengan model organisasi pembelajaran lain ( Yang, 2003; Yang,Watkins , \& Marsick, 2004, Song, Ji Hoon,at al.2009) - Keempat, kerangka telah banyak digunakan oleh berbagai peneliti dalam berbagai pengaturan penelitian ( Dymock , 2003; David, A. Herrera. 2007; Haque, Md Mahbubul, 2008; Rowe, Allen, 2010).

Berdasarkan hasil penelitian Kohli et al (1998) dalam Agapita Sri Haryanti. (2006) menunjukan bahwa karyawan yang tumbuh dalam organisasi yang mendukung pembelajaran ternyata mampu mencapai peningkatan kinerja yang lebih baik, hal ini menjadi bukti bahwa organisasi pembelajaran ternyata memiliki pengaruh positif dan signifikan guna meningkatkan kinerja karyawan. Ini dikuatkan oleh penelitian oleh Akhmad Supriadi (2007) memperoleh hasil emprik bahwa organisasi pembelajaran memberikan kontribusi positif dalam upaya manajemenen meningkatkan kinerja karyawan, dari sini dapat dianalisis bahwa untuk meningkatkan kinerja karyawan di perlukan penerapan organisasi pembelajaran. Kinerja menurut Bernardin (2013 : 241) adalah sebagai hasil pekerjaan yang telah dilakukan berdasarkan fungsi pekerjaan atau aktivitas tertentu pada jangka waktu tertentu. Dalam penelitian ini mengukapkan kriteria kinerja pegwai menggunakan teori Gomes (2003:142), dikarenakan teori ini sudah di uji secara empirik dan dibanyak tempat, beberapa penelitian yang menggunakan model ini seperti yang dilakukan oleh Agapita Sri Haryanti (2012) mengukapkan bahwa model yang diungkapkan gomes menjadi pendekatanya sistematis sehingga dapat menjadi acuan dalam penlian kinerja karyawan, demensi kierja pegawai dengan teori gomes (2003) mengungkapkan ada delapan kriteria yang menjadi perhatian untuk melihat deskripsi perilaku individu secara spesifik dalam kinerja karyawan yang berdasarkan perilaku yang spesifik.

Gambaran paradigma penelitian pengaruh manajemen perubahan terhadap penerapan organisasi pembelajaran serta dampaknya terhadap kinerja pegawai, seperti gambar 1 




Gambar 1

\section{Metode Penelitian}

Dalam penelitian ini metode yang digunakan adalah metode survey explanotary dikarenakan untuk mengetahui hubungan kausal antara variabel dan gambaran umum antar variabel, dalam penelitian ini variabelnya adalah manajemen perubahan (X), organisasi pembelajaran (Y) dan kinerja pegawai (Z). Survey explanotary merupakan riset awal, riset ini ditindaklanjuti kepada metode deskritif dan verifikatif (Istijanto, 2006 :20). Metode verifikatif digunakan untuk mengetahui sejauh mana pengaruh variabel independent $(X)$, variabel intervening $(\mathrm{Y})$ terhadap variabel dependent $(\mathrm{Z})$, serta mengetahui hubungan antara variabel penelitian melalui pengujian hipotesis dengan menggunakan perhitungan statistik (Nazir, 2005). Tipe penelitian ini adalah penelitian kausal yang bertujuan untuk menguji pengaruh dan atau hubungan antara variabel-variabel dalam penelitian. Dalam penelitian ini juga dijaring dengan menggunakan alat pengumpulan data tertentu, yaitu kuesioner (Mudrajat Kuncoro, 2003:8)

\section{Sampel}

Sampel yang digunakan dalam penelitian ini adalah dengan cara simple Sratified propotional random sampling. Dimana Sratified propotional random sampling yaitu mengambil sampel pada setiap tingkatan pada penelitian ini terdiri dari tujuh kelompok kerja, setiap kelompok kerja diambil sampel yang secara proposional Mengingat besarnnya populasi, maka peneliti mengambil sampel 100 pegawai PT KAI (PERSERO) DAOP 2 Bandung.

Ukuran sampel ditentukan berdasarkan metode pengukuran sampel yang dikemukakan oleh Slovin dan Sevilla dengan rumus sebagai berikut:

$$
=95.02100
$$

\footnotetext{
Dimana :

$\mathrm{i} \quad=$ ukuran sampel minimal

$\mathrm{N} \quad=$ ukuran populasi

$\mathrm{e} \quad=$ tingkat kesalahan yang ditolerir
}

Dalam sampel penelitian ini, menetapkan tingkat kesalahan sebesar 10\%. Maka ukuran sampel yang dibutuhkan untuk penelitian ini yaitu sebesar 100 responden dari populasi sebesar 1909 pegawai. Dan yang memenuhi kriteria yang bisa di ambil sebagai 
sampel adalah pegawai yang masa kerjanya minimal lima tahun masa kerja yaitu sebesar 1345 .

\section{Analisis Jalur (Path Analysis)}

Analisis jalur adalah suatu metode grafik dalam mengkaji pengaruh-pengaruh langsung dan akibat tidak langsung dari variabel penyebab (eksogenuos) terhadap variabel akibat (endogenous). Metode ini untuk memotret dan menguji "teori" analisis jalur adalah suatu bentuk terapan dari analisis multi regresi, membantu menguji hipotesis yang kompleks, dengan menggunakanya dapat menghitung pengaruh langsung dan tidak langsung.

Penelitian ini dilakukan untuk mencari hubungan antar variabel independent/endogen atau akibat. Oleh karena itu analisis data dilakukan dengan menggunakan analisis jalur (path analysis)

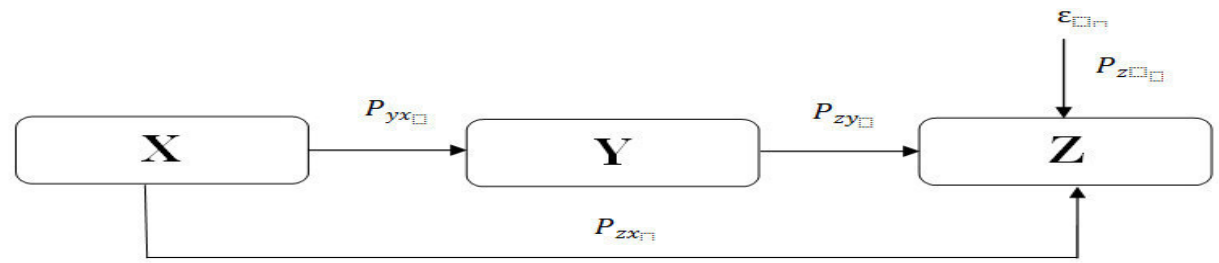

Gambar 2

Dimana :

\section{Diagram jalur antara variabel}

$\mathrm{X}=$ Manajemen Perubahan (Change Management)

$\mathrm{Y} \quad=$ Organisasi pembelajaran (Learning Organization)

$\mathrm{Z} \quad=$ Kinerja Pegawai

Gambar 2 menjelaskan diagram jalur yang menyatakan hubungan kausal X dan Y sebagai penyebab dan $\mathrm{Z}$ sebagai akibat, dimana $\mathrm{Y}$ adalah variabel intervening, teknik perhitungan analisis jalur (path analysis) dengan menggunakan software SPSS 22 for windows. Berdasarkan teknik analisis data yang digunakan untuk menjawab tujuan penelitian dua, tiga, dan empat, maka diagram jalurnya memiliki dua persamaan sub struktur, yaitu :

$\mathrm{Y}=\mathrm{P}_{\mathrm{xy}} \mathrm{X}+\varepsilon 1$

$\mathrm{Z}=\mathrm{P}_{\mathrm{ZX}} \mathrm{Y}+\varepsilon 2$

Keterangan :

$\mathrm{P}_{\mathrm{xy}} \mathrm{X}+\varepsilon 1 \quad$ : Koefisien jalur $\mathrm{X}$ terhadap $\mathrm{Y}$

$\mathrm{P}_{\mathrm{zX}} \mathrm{X}+\varepsilon 2 \quad$ : Koefisien jalur $\mathrm{Y}$ terhadap $\mathrm{Z}$

$\varepsilon \quad$ : epsilon

\section{Hipotesis}

Hipotesis penelitian ini sebagai berikut :

1. Manajemen perubahan berpengaruh terhadap organisasi pembelajaran pada PT. KAI (PERSERO) DAOP II Bandung

2. Organisasi Pembelajaran berpengaruh terhadap kinerja pegawai pada PT. KAI (PERSERO) DAOP II Bandung

3. Manajemen perubahan berpengaruh terhadap kinerja pegawai baik langsung maupun tidak langsung melalui organisasi pembelajaran pada PT. KAI (PERSERO) DAOP II Bandung 


\section{Hasil dan Pembahasan}

\section{Pengaruh Manajemen Perubahan terhadap Organisasi Pembelajaran}

Uji hipotesis ini pertama dalam penelitian ini adalah mengetahui pengaruh Pengaruh Manajemen Perubahan (X) terhadap Organisasi Pembelajaran (Y) Atau pengujian hipotesis digunakan uji $\mathrm{F}$, data yang diperoleh diolah dengan menggunakan program komputer SPSS 22.0 for Windows. Hasil pengolahan data tersebut ditunjukkan pada Tabel 1

Tabel 1

\begin{tabular}{|c|c|c|c|c|c|c|}
\hline \multicolumn{7}{|c|}{$\mathrm{ANOVA}^{\mathrm{a}}$} \\
\hline \multicolumn{2}{|c|}{ Model } & $\begin{array}{c}\text { Sum of } \\
\text { Squares }\end{array}$ & df & $\begin{array}{c}\text { Mean } \\
\text { Square }\end{array}$ & $\mathrm{F}$ & Sig. \\
\hline \multirow[t]{3}{*}{1} & Regression & 2761,325 & 1 & 2761,325 & 62,178 &, $000^{\mathrm{b}}$ \\
\hline & Residual & 4352,189 & 98 & 44,410 & & \\
\hline & Total & 7113,514 & 99 & & & \\
\hline \multicolumn{7}{|c|}{ a. Dependent Variable: Organisasi Pembelajaran } \\
\hline \multicolumn{7}{|c|}{ b. Predictors: (Constant), Manajemen Perubahan } \\
\hline
\end{tabular}

Sumber : Data kuesioner yang telah diolah, 2014

Berdasarkan tabel ANOVA tabel 1. Dapat diketahui besarnya $F_{\text {hitung }}$ melalui uji ANOVA atau $F_{\text {test }}$, yaitu sebesar 62,178 dengan tingkat signifikansi sebesar 0,000. Harga ini selanjutnya dikonsultasikan dengan $\mathrm{F}$ tabel, dengan didasarkan pada $\mathrm{dk}$ pembilang $=1 \mathrm{dan} \mathrm{dk}$ penyebut $(100-1-1)=98$, sehingga nilai $F_{\text {tabel }}$ diperoleh sebesar 3,94. Dikarenakan $F_{\text {hitung }}>$ $\mathrm{F}_{\text {tabel }}(62,178>3,94)$, karena $\mathrm{F}$ hitung lebih besar dari $\mathrm{F}$ tabel maka koefisien korelasi yang diuji adalah signifikan untuk $\alpha=5 \%$, probabilitas $(0,000)$ jauh lebih kecil dari 0,05 , maka Ho ditolak, artinya $\mathrm{Y}$ dipengaruhi oleh $\mathrm{X}$ atau organisasi pembelajaran dipengaruhi oleh manajemen perubahan.

Untuk menentukan persamaan struktural dari pengaruh manajemen perubahan terhadap organisasi pembelajaran perlu mengetahui nilai dari koefisien determinasi yang dijelaskan Tabel 2, berikut:

\section{Tabel 2}

Output Regresi XY

\begin{tabular}{|l|c|r|r|r|}
\hline Model & \multicolumn{1}{|c|}{$\mathrm{R}$} & R Square & $\begin{array}{c}\text { Adjusted R } \\
\text { Square }\end{array}$ & $\begin{array}{r}\text { Std. Error of } \\
\text { the Estimate }\end{array}$ \\
\hline 1 &, $623^{\mathrm{a}}$ &, 388 &, 382 & 6,66409 \\
\hline \multicolumn{7}{|c|}{ a. Predictors: (Constant), Manajemen Perubahan } \\
\hline \multicolumn{6}{|l}{ b. Dependent Variable: Organisasi Pembelajaran } \\
\hline
\end{tabular}

Sumber : Data kuesioner yang telah diolah, 2014

Berdasarkan Tabel 2. Dapat dilihat nilai $R$ Square adalah 0,388. Nilai ini dikonversikan dalam bentuk persen menjadi koefisien determinasi, yaitu sebesar 38,8\%. Nilai residunya adalah 0,612 (didapat dari 1- R Square). Nilai ini menunjukan besarnya pengaruh manajemen perubahan terhadap organisasi pembelajaran sebesar $38,8 \%$, sedangkan $61,2 \%$ dipengaruhi faktor lain. diketahui nilai koefisien determinasi $\mathrm{R}^{2} \mathrm{yx}=(0,623)(0,623)=0,388$, dan besarnya koefisien residu $\rho_{e i}=\sqrt{1-0,388}=0.782$. Maka dapat ditentukan persamaan struktural yang baru dari model Y yaitu sebagai berikut: 


$$
Y=0,623+0.782 \varepsilon 1
$$

Dalam penelitian ini, diagram jalur pengujian hipotesis menunjukkan pengaruh manajemen perubahan (variabel X) terhadap organisasi pembelajaran (variabel Y). Seperti dijelaskan pada Gambar 3

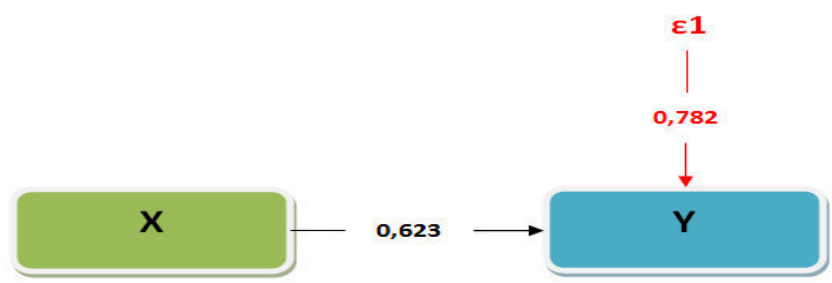

Gambar 3

Diagram Jalur Pengujian Hipotesis Kedua

\section{Pengaruh Organisasi Pembelajaran terhadap Kinerja Pegawai}

Uji hipotesis ini pertama dalam penelitian ini adalah mengetahui pengaruh Pengaruh Organisasi Pembelajaran (Y) terhadap Kinerja Pegawai (Z). Hasil pengolahan data tersebut ditunjukkan pada Tabel 3

\section{Tabel 3}

ANOVA YZ

\begin{tabular}{|l|l|r|r|r|c|c|}
\hline \multicolumn{7}{|l|}{ ANOVA $^{\text {a }}$} \\
\hline \multirow{2}{|l|}{ Model } & Sum of Squares & df & Mean Square & F & Sig. \\
\hline \multirow{3}{*}{1} & Regression & 5594,584 & 1 & 5594,584 & 75,928 &, $000^{\mathrm{b}}$ \\
\cline { 2 - 7 } & Residual & 7220,949 & 98 & 73,683 & & \\
\cline { 2 - 7 } & Total & 12815,532 & 99 & & & \\
\hline
\end{tabular}

Sumber : Data kuesioner yang telah diolah, 2014

Berdasarkan tabel ANOVA tabel 3, dapat diketahui besarnya $F_{\text {hitung }}$ melalui uji ANOVA atau $F_{\text {test }}$, yaitu sebesar 75,928 dengan tingkat signifikansi sebesar 0,000. Harga ini selanjutnya dikonsultasikan dengan $\mathrm{F}$ tabel, dengan didasarkan pada $\mathrm{dk}$ pembilang $=1 \mathrm{dan} \mathrm{dk}$ penyebut $(100-1-1)=98$, sehingga nilai $F_{\text {tabel }}$ diperoleh sebesar 3,94. Dikarenakan $F_{h i t u n g}>$ $F_{\text {tabel }}(75,928>3,94)$, karena $F$ hitung lebih besar dari $\mathrm{F}$ tabel maka koefisien korelasi yang diuji adalah signifikan untuk $\alpha=5 \%$, probabilitas $(0,000)$ jauh lebih kecil dari 0,05 , maka Ho ditolak, artinya variabel $\mathrm{Z}$ dipengaruhi oleh variabel $\mathrm{Y}$ atau kinerja pegawai dipengaruhi oleh organisasi pembelajaran.

Untuk menentukan persamaan struktural dari pengaruh organisasi pembelajaran terhadap kinerja pegawai perlu mengetahui nilai dari koefisien determinasi yang dijelaskan Tabel 4, berikut:

\section{Tabel 4}

Output Regresi YZ

\begin{tabular}{|l|c|r|r|r|}
\hline \multicolumn{5}{|c|}{ Model Summary } \\
\hline Model & R & R Square & $\begin{array}{c}\text { Adjusted R } \\
\text { Square }\end{array}$ & $\begin{array}{c}\text { Std. Error of } \\
\text { the Estimate }\end{array}$ \\
\hline 1 &, $661^{\mathrm{a}}$ &, 437 &, 431 & 8,58389 \\
\hline \multicolumn{7}{|c|}{ a. Predictors: (Constant), Organisasi Pembelajaran } \\
\hline
\end{tabular}

Sumber : Data kuesioner yang telah diolah, 2014 
Berdasarkan Tabel 4 Dapat dilihat nilai $\mathrm{R}$ Square adalah 0,437. Nilai ini dikonversikan dalam bentuk persen menjadi koefisien determinasi, yaitu sebesar 43,7\%. Nilai residunya adalah 0,563 (didapat dari 1 - $\mathrm{R}$ Square). Nilai ini menunjukan besarnya pengaruh organisasi pembelajaran terhadap kinerja pegawai sebesar $43,7 \%$, sedangkan $56,3 \%$ dipengaruhi faktor lain. diketahui nilai koefisien determinasi $\mathrm{R}^{2} \mathrm{yx}=(0,661)(0,661)=0,437$, dan besarnya koefisien residu $\rho_{e i}=\sqrt{1-0,437}=0.750$. Maka dapat ditentukan persamaan struktural yang baru dari model Y yaitu sebagai berikut:

$$
Y=0,661+0.750 \varepsilon 2
$$

Dalam penelitian ini, diagram jalur pengujian hipotesis menunjukkan pengaruh organisasi pembelajaran (variabel Y) terhadap kinerja pegawai (variabel Z). Seperti dijelaskan pada Gambar 4

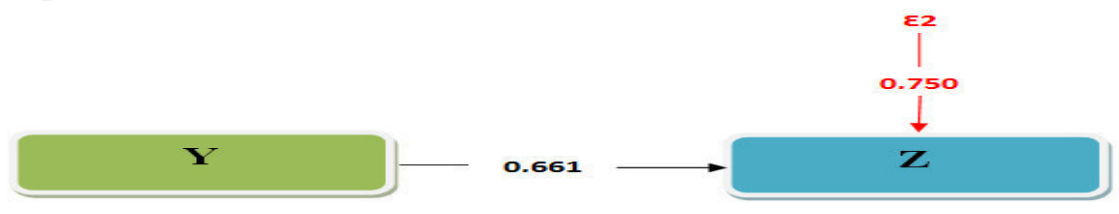

\section{Diagram Jalur Pengujian Hipotesis Ketiga}

\section{Pengaruh Manajemen Perubahan terhadap Kinerja Pegawai melalui Organisasi Pembelajaran pada PT KAI (PERSERO) DAOP II Bandung}

Dalam bagian ini akan dijabarkan pengaruh langsung manajemen perubahan terhadap kinerja pegawai dan pengaruh tidak langsung manajemen perubahan terhadap kinerja pegawai, yaitu dengan melalui organisasi pembelajaran. Pengaruh langsung dan tidak langsung tersebut adalah sebagai berikut :

\section{Pengaruh langsung manajemen perubahan terhadap kinerja pegawai}

Uji hipotesis ini pertama dalam penelitian ini adalah mengetahui pengaruh Pengaruh Manajemen Perubahan (X) terhadap Kinerja Pegawai (Z). Hasil pengolahan data tersebut ditunjukkan pada Tabel 5.

Tabel 5

ANOVA XZ

\begin{tabular}{|l|l|r|r|r|r|c|}
\hline \multicolumn{8}{|c|}{ ANOVA $^{\text {a }}$} \\
\hline \multirow{2}{*}{1} & Model & Sum of Squares & df & Mean Square & F & Sig. \\
\cline { 2 - 7 } & Regression & 5991,377 & 1 & 5991,377 & 86,041 &, $000^{\text {b }}$ \\
\cline { 2 - 7 } & Residual & 6824,155 & 98 & 69,634 & & \\
\cline { 2 - 7 } & Total & 12815,532 & 99 & & & \\
\hline \multicolumn{2}{|l|}{ a. Dependent Variable: Kinerja Pegawai } \\
\hline
\end{tabular}

Sumber : Data kuesioner yang telah diolah, 2014

Berdasarkan tabel ANOVA tabel 5, dapat diketahui besarnya $F_{\text {hitung }}$ melalui uji ANOVA atau $F_{\text {test }}$, yaitu sebesar 86,041 dengan tingkat signifikansi sebesar 0,000. Harga ini selanjutnya dikonsultasikan dengan $\mathrm{F}$ tabel, dengan didasarkan pada $\mathrm{dk}$ pembilang $=1 \mathrm{dan} \mathrm{dk}$ 
penyebut $(100-1-1)=98$, sehingga nilai $F_{\text {tabel }}$ diperoleh sebesar 3,94. Dikarenakan $F_{\text {hitung }}>$ $\mathrm{F}_{\text {tabel }}(86,041>3,94)$, karena $\mathrm{F}$ hitung lebih besar dari $\mathrm{F}$ tabel maka koefisien korelasi yang diuji adalah signifikan untuk $\alpha=5 \%$, probabilitas $(0,000)$ jauh lebih kecil dari 0,05 , maka Ho ditolak, artinya variabel $\mathrm{Z}$ dipengaruhi oleh variabel $\mathrm{X}$ atau kinerja pegawai dipengaruhi oleh manajemen perubahan.

Untuk menentukan persamaan struktural dari pengaruh manajemen perubahan terhadap kinerja pegawai perlu mengetahui nilai dari koefisien determinasi yang dijelaskan 6 , berikut;

\section{Tabel 6}

Output Regresi XZ

\begin{tabular}{|l|c|r|r|r|}
\hline \multicolumn{6}{|c|}{ Model Summary } \\
\hline Model & $\mathrm{R}$ & R Square & $\begin{array}{c}\text { Adjusted R } \\
\text { Square }\end{array}$ & $\begin{array}{r}\text { Std. Error of } \\
\text { the Estimate }\end{array}$ \\
\hline 1 &, $684^{\mathrm{a}}$ &, 468 &, 462 & 8,34471 \\
\hline \multicolumn{2}{|l|}{ a. Predictors: (Constant), Manajemen Perubahan } \\
\hline
\end{tabular}

Sumber : Data kuesioner yang telah diolah, 2014

Berdasarkan Tabel 6 Dapat dilihat nilai $\mathrm{R}$ Square adalah 0,468. Nilai ini dikonversikan dalam bentuk persen menjadi koefisien determinasi, yaitu sebesar 46,8\%. Nilai residunya adalah 0,532 (didapat dari 1 - R Square). Nilai ini menunjukan besarnya pengaruh manajemen perubahan terhadap kinerja pegawai sebesar 46,8\%, sedangkan 53,2\% dipengaruhi faktor lain. diketahui nilai koefisien determinasi $\mathrm{R}^{2} \mathrm{yx}=(0,684)(0,684)=0,468$, dan besarnya koefisien residu $\rho_{e i}=\sqrt{1-0,468}=0.729$. Maka dapat ditentukan persamaan struktural yang baru dari model Y yaitu sebagai berikut:

$$
Y=0,684+0.729 \varepsilon 3
$$

Dalam penelitian ini, diagram jalur pengujian hipotesis menunjukkan pengaruh manajemen perubahan (variabel X) terhadap kinerja pegawai (variabel Z). Seperti dijelaskan pada Gambar 5

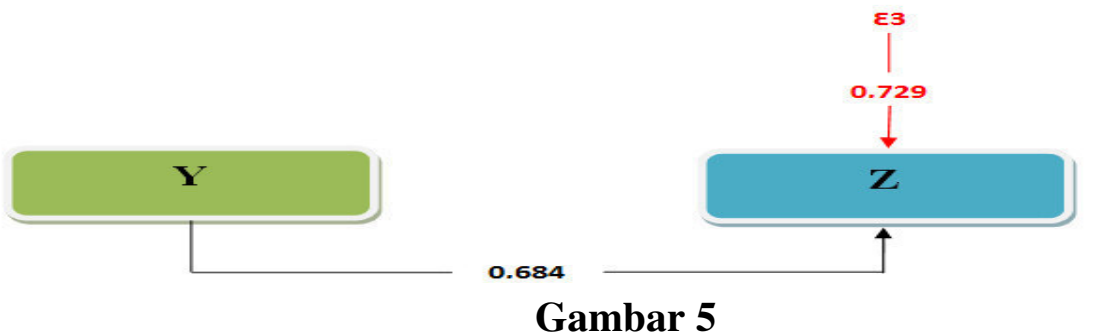

Diagram Jalur Pengujian Hipotesis Kempat

\section{Pengaruh tidak langsung manajemen perubahan terhadap kinerja pegawai melalui organisasi pembelajaran}

Pengaruh manajemen perubahan terhadap organisasi pembelajaran dapat dilihat dari koefisien jalur $\mathrm{X}$ terhadap $\mathrm{Y}\left(\mathrm{P}_{\mathrm{yx}}\right)$. Pengaruh organisasi pembelajaran terhadap kinerja pegawai dapat dilihat dari koefisien jalur $\mathrm{Y}$ terhadap $\mathrm{Z}\left(\mathrm{P}_{\mathrm{zy}}\right)$. Pengaruh manajemen perubahan terhadap kinerja pegawai dapat dilihat dari koefisien jalur $\mathrm{X}$ terhadap $\mathrm{Z}\left(\mathrm{P}_{\mathrm{zx}}\right)$. Besarnya pengaruh tidak langsung manajemen perubahan terhadap kinerja pegawai melalui organisasi pembelajar dapat dihitung melalui formula sebagai berikut : 


$$
\begin{array}{llll}
\mathrm{P}_{\mathrm{zx}} & =\mathrm{P}_{\mathrm{yx}} \mathrm{x} & \mathrm{P}_{\mathrm{zy}} \\
\mathrm{P}_{\mathrm{zx}} & =0,623 \quad \mathrm{x} & 0,661=0,411
\end{array}
$$

Dari perhitungan tersebut di dapat sebesar 0,411 . Ini berarti besarnya pengaruh tidak langsung manajemen perubahan terhadap kinerja pegawai melalui organisasi pembelajaran sebesar $=41,1 \%$.

Dari keseluruhan hasil penelitian maka dapat digambarkan dengan analisis jalur sebagai berikut :

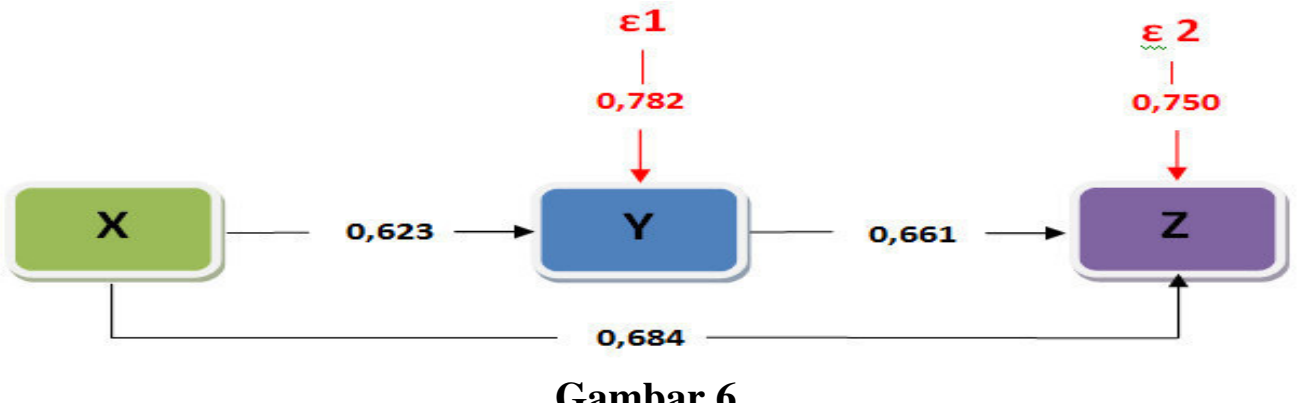

\section{Gambar 6 \\ Diagram Jalur Hasil Penelitian}

Dari hasil penelitian ini maka persamaan strukturalnya adalah sebagai berikut :

1. Persamaan struktural pertama

$\mathrm{Y}=\mathrm{P}_{\mathrm{yx}} \mathrm{X}+$ py $\varepsilon 1$

$Y=0,623 X+0,782 \varepsilon 1$
2. Persamaan struktural kedua

$$
\begin{aligned}
& Z=P_{z y} Y+p z \varepsilon 2 \\
& Z=0,661 Y+0,750 \varepsilon 2
\end{aligned}
$$

Dari hasil penelitianyang terlihat pada gambar 6, dapat disimpulkan bahwa besar pengaruh manajemen perubahan terhadap organisasi pembelajaran adalah 0,623 , yang berarti jika manajemen perubahan naik 1, maka organisasi pembelajaran akan naik sebesar 0,623. Besar pengaruh organisasi pembelajaran terhadap kinerja pegawai adalah 0,661 , yang berarti jika organisasi pembelajaran naik 1, maka kinerja pegawai naik sebesar 0,661. Besar pengaruh langsung manajemen perubahan terhadap kinerja pegawai sebesar 46,8\%, sedangkan penagaruh tidak langsung manajemen perubahan terhadap kinerja pegawai melalui organisasi pembelajaran sebesar $41,1 \%$.

Total pengaruh langsung lebih besar daripada total pengaruh tidak langsung. Ini berarti bahwa hubungan antara manajemen perubahan dengan kinerja pegawai dipengaruhi oleh organisasi pembelajaran, namun pengaruhnya rendah. Ini berarti adanya organisasi pembelajaran dalam manajemen perubahan hanya sedikit mempengaruhi kinerja pegawai. Hal ini disebabkan masih belum optimalnya penerapan organisasi pembelajaran yang diterapkan pada PT KAI (PERSERO) DAOP II Bandung. Sehingga tidak dapat meningkatkan pengaruh manajemen perubahan terhadap kinerja pegawai. Penerapan organisasi pembelajaran pada PT KAI (PERSERO) DAOP II Bandung, belum dirasakan seluruh pegawai, seperti studi banding hanya sebagaian kecil pegawai yang mendapatkan kesempatan dan belum adanya forum resmi knowledge sharing. Permintaan dan dialog yang sudah diwadahi oleh DPD 2 SPKA DAOP II Bandung, dalam aktivitasnya SPKA masih belum optimal, ini dilihat dari tidak semua tuntutan inti pegawai dapat dikabulkan oleh pihak manajemen, selain itu pemberdayaan pegawai dalam penentuan rancangan kerja dan anggara (RKA) tidak semua pegawai bisa secara langsung memberikan masukan untuk perusahaan, dan masih kurang dukungan dari pimpinan dalam menggunakan pembelajaran untuk menciptakan perubahan dan untuk memindahkan organisasi ke arah yang baru. 


\section{Simpulan dan Saran}

\section{Simpulan}

Berdasarkan hasil pembahasan dalam penelitian ini maka dapat disimpulkan hal-hal sebagai berikut :

1. Dari hasil penelitian diketahui bahwa manajemen perubahan berpengaruh terhadap organisasi pembelajaran pada PT KAI (PERSERO) DAOP II Bandung adalah 38,8\%. Dilihat dari nilai koefisien determinasi pengaruhnya tergolong kuat. Pengaruh manajemen perubahan terhadap organisasi pembelajaran berbanding lurus berarti ketika manajemen perubahan tinggi maka organisasi pembelajar juga tinggi.

2. Dari hasil penelitian diketahui bahwa organisasi pembelajaran berpengaruh terhadap kinerja pegawai PT KAI (PERSERO) DAOP II Bandung adalah 43,7\%. Dilihat dari nilai koefisien determinasi pengaruhnya tergolong kuat. Pengaruh organisasi pembelajaran terhadap kinerja pegawai berbanding lurus berarti ketika organisasi tinggi maka kinerja pegawai juga tinggi.

3. Dari hasil penelitian diketahui bahwa manajemen perubahan terhadap kinerja pegawai melalui organisasi pembelajaran PT KAI (PERSERO) DAOP II Bandung, total pengaruh tidak langsung adalah $41,1 \%$. Sedangkan manajemen perubahan terhadap kinerja pegawai pembelajaran PT KAI (PERSERO) DAOP II Bandung, total pengaruh langsung adalah $46,8 \%$. Berarti pengaruh langsung manajemen perubahan terhadap kinerja pegawai lebih besar daripada pengaruh tidak langsungnya melalui organisasi pembelajaran. Hal ini Hal ini disebabkan masih belum optimalnya penerapan organisasi pembelajaran yang diterapkan pada PT KAI (PERSERO) DAOP II Bandung.

\section{Saran}

1. Penelitian selanjutnya hendaknya dilakukan pada objek dengan skala yang lebih luas dengan mengambil semua DAOP dan Sub Divre PT KAI.

2. Penelitian selanjutnya hendaknya mengadakan FGD (Focus Group Discussion) baik dari pihak manajemen, pegawai, pelanggan dan pemerintah, dalam menjalankan manajemen perubahan yang sedang dilakukan.

3. Penelitian selanjutnya dapat mengkaitkan organisasi pembelajaran dengan variabel baru seperti readiness to change, karena kesiapan perubahan tidak akan optimal tanpa adanya dukungan organisasi pembelajaran yang secara terus menerus melakukan perbaikan.

4. PT KAI (PERSERO) DAOP II Bandung, dalam upaya melakukan proses manajemen perubahan lebih intensif dalam melakukan penyebaran visi dengan melakukan komunikasi dua arah, agar dapat menjaring aspirasi pegawai lebih banyak, dan saluran komunikasi berjalan baik. Dengan baiknya saluran komunikasi ini akan pegawai lebih dihargai oleh perusahaan sehingga akan menilngkatkan rasa memiliki perusahaan.

5. PT KAI (PERSERO) DAOP II Bandung, dalam upaya melakukan proses manajemen perubahan, hendaknya perusahaan menyakinkan bahwa arah perubahan kearah yang positf, seperti dengan meningkatnya keuntungan perusahaan, hendaknya perusahaan lebih menyakinkan pegawai bahwa proses perubahan ini berjalan positif, dengan cara salah satunya meningkatkan kesejahtraan pegawai baik berupa materil dan non materil, sehingga proses perubahan dapat terus berjalan. 


\section{Daftar Pustaka}

Agapita Sri Haryanti. 2006. Analisis Faktor - Faktor yang Menjadi Prediktor Organisasi Pembelajaran Untuk Meningkatkan Kinerja Karyawan (Study Kasus Pada PT. Gramedia Pustaka Utama Jakarta).Tesis. Semarang : Undip.

Akhmad Supardi 2007. Analisis Implementasi Learning Orgnization Dalam Upaya Mendukung Peningkatan Kinerja Karyawan di PT KH. Tidak dipublikasikan (Tesis). Bandung : Unpad.

Albert, Michael. 2005. Managing Change: Creating a Learning Organization Focused on Quality. Problems and Perspectives in Management Journal, 1/2005.

Albert, Michael. 2006. Managing Change at HP Lab: Perspectives for Innovation, Knowledge Management and Becoming a Learning Organization. Journal The Business Review, Cambridge 5.2 (Summer 2006): 17-22.

Alireza Shirvani, Mashallah Valikhani Dehaghani, Seyed Hassan Mossavi. 2013. Change Management in Public Sector : A case Study of Gas Distribution Firm. Iran : Management Science Letters Journal 3 (2013) 1751-1756.

Amin Soebagyo. 2009. Kajian Atas Pengaruh Tahapan Proses Transformasi Dari Koter Pada Keberhasilan Proses Transformasi Perusahaan Dalam Perspektif Manajemen dan Karyawan. Tidak dipublikasikan (Tesis). Bandung : Unpad.

Anderson, Frank. Rob Dare \& Rich Stillman. 2004. The Hanscorn Learning Organization : a solution for the information age, Defense AT \& L Journal, September-Oktober, 2004.

Appelbaum, Steven H., Habashy, Sally., Malo, Jean-Luc \& Shafiq, Hisham. 2012. Back to the future: revisiting Kotter's 1996 change model. Journal of Management Development, Vol. 31 Iss: 8 pp. 764 - 782. (C) Emerald Group Publishing Limited

Bernardin. H John \& Joyce. E.A. Russell. 2013. Human Resources Management, An Experiential Approach. Sixth Edition. New York : McGraw-Hill International Edition.

Burnes, Bernard. 2000. Managing Change. Essex-England : Pearson Edication Limited.

David, A. Herrera. 2007. A Validation of The Learning Organization as a Driver of Performance Improvement. UMI by ProQuest Information and Learning Company. United States. Dissertation. Capella University.

Gomes, Faustic C. 2003. Manajemen Sumber Daya Manusia. Yogyakarta : CV. Andi Offset.

Haque, Md Mahbubul. 2008. A Study of The Relationship Between The Learning Organization And Organizational Readiness For Change. UMI by ProQuest LLC. United States. Dissertation. Graduate School of Education and Psychology Pepperdine University. 
Istijanto. 2006. Riset Sumber Daya Manusia. Jakarta : PT Gramedia Pustaka Utama

Kotter, John P.2000. Leading Change: Why Transformation Efforts Fail. HBR OnPoint .

USA : Harvard Business School Publishing Corporation.

Marquardt, Michael.J. 2002. Building The Learning Organization. Mastering The 5 Elements For Corporate Learning. $2^{\text {nd }}$ Edition. Davies-Black Publishing, Inc. Palo Alto, CA.

Mathis, R.L \& Jackson, J.H., 2004. Human Resource Management. International Student Edition ed.

Mohammad Taheri R. Majid Khazai. Elahe Nasiri F. Saeed Mahdavi Nasr. 2013. The Relationship between Learning Organization and Organizational Readiness for Change According to Seven Dimensions of Learning Organization. Journal of Basic and App;ied Scientific Research. 3(5)631-636, 2013. ISSN 2090-4304. Text Road Publication.

Mudrajat Kuncoro. 2003. Metode Riset Untuk Bisnis dan Ekonomi. Jakarta : Erlangga

Muhamad Haniv 2012. Peran Sumber Daya Manusia dan Sistem Model Organisasi pembelajaran (Learning Organization) Dalam Reformasi Birokrasi Perpajakan di Kantor Direktorat Jenderal Pajak (Studi Kasus Pelayanan Pajak di Kanwil DJP jakarta). Bogor : Manajemen Bisnis (Disertasi) Sekolah Pascasarjana IPB.

Nazir. 2005. Metode penelitian. Bogor : Ghalia Indonesia.

Omar Al-Jaradat. Mohammed Nagresh. Abdullah Al-Shegran \& Nura Jadellah. 2013. Impact of change management on the performance of employees in university libraries in Jordan. European Journal of Business and Management ISSN 2222-1905 (Paper) ISSN 2222-2839 (Online) Vol.5, No.2, 2013. www.iiste.org.

Rhenald Kasali.2007. Change (Manajemen Perubahan dan Manajemen Harapan). Jakarta : PT Ikrar Mandiri abdi.

Rowe, Allen. 2010. Looking at Extension as a Learning Organization. Journal of Extension August 2010 Volume 48 Number 4 Article Number 4 RIB, 1-7.

Rush, Rosalee Billingslea. 2011. Learning Organization Principles: The Impact On a Midwest State Government as Perceived by Its Employees. A Dissertation Faculty of The Graduate College Western Michigan University. USA. UMI Disssertation Publishing Copyright 2011 by ProQuest LL.

Small, A. 2006. Towards A Framework For Organizational Learning. The Learning Organization, 13(3), 276-299.

Song, Ji Hoon,. Joo, Baek-Kyoo (Brian), \& Chermack, Thomas J.2009. The Dimensions of Learning Organization Questionnaire (DLOQ): A Validation Study in a Korean Context. Human Resource Development Quarterly, vol. 20, no. 1, Spring 2009 () Wiley Periodicals, Inc. 
Stagalas, Nicole. 2010. Improving Change Implementation Practical adaptation of Kotter's Model. OD Practitioner vol.42 no. 1 2010. P 31-38.

Watkins, K., \& Marsick, V.1993. Sculpting the learning organization: Lessons in the art and science of systemic change. San Francisco: Jossey-Bass.

Watkins, K., \& Marsick, V. 1996. In action: Creating a learning organization. Alexandria, VA: American Society for Training and Development.

Watkins, K. E., \& Marsick, V. J. 1999. Sculpting the learning community: New forms of working and organizing. National Association of Secondary School Principals: NASSP Bulletin, 83(604), 78-87.

Wibowo. 2012. Manajemen Perubahan. Jakarta : PT Raja Grafindo Persada.

Winardi. 2010. Manajemen Perubahan (Management of Change). Jakarta : Prenada Media Group.

Yang, B. 2003. Identifying Valid And Reliable Measures For Dimensions of A Learningculture. Advances in Developing Human Resources, 5(2), 152-162.

Yang, B., Watkins, K. E., \& Marsick, V. J. 2004. The Construct of The Learning Organization: Dimensions, Measurement, and Validation. Human Resource Development Quarterly, 15(1), 31-56. Wiley Periodicals, Inc. 